\title{
SOCIOLOGINIAI URBANIZUOTOS APLINKOS TYRIMAI: PATIRTIS IR KRYPTYS
}

\author{
Indrè Gražulevičiūtè-Vileniškè \\ Kauno technologijos universitetas
}

\begin{abstract}
Anotacija
Vis daugiau dèmesio skiriant socialinei dimensijai tokiose aplinkos formavimo srityse kaip teritoriju planavimas ar architektūrinis projektavimas, siekiant kurti aplinką, kuri ne tik būtų patogi, bet ir estetiška bei psichologiškai priimtina, svarbu įvertinti sociologinių tyrimų metodų taikymo miesto medžiaginei ir socialinei aplinkai suprasti patirtị bei galimybes. Siekiant šio tikslo, straipsnyje apžvelgta sociologinių urbanizuotos aplinkos tyrimų patirtis, išskiriant būdingus tyrimų atvejus pasaulyje ir jų atitikmenis Lietuvoje. Remiantis literatūra išskirti ir suklasifikuoti sociologinių urbanizuotos aplinkos tyrimų tipai ir pagrindiniai tokių tyrimų tikslai.

PAGRINDINIAI ŽODŽIAI: sociologinis tyrimas, sociologinio tyrimo metodas, urbanizuota aplinka, miestovaizdis, miesto socialinè aplinka.
\end{abstract}

\begin{abstract}
The social dimension is gaining an increasing importance in the fields of shaping our environment, such as territorial planning and architectural design. In order to create the living environment, which would be not only comfortable, but also aesthetic and psychologically acceptable, it is important to analyze the experience and possibilities of application of sociological research methods to physical and social environment of urbanized areas. In order to reach this aim, the article presents the review of experience of application of the sociological research methods to urban environment distinguishing the characteristic cases in this field and their analogies in Lithuanian practice and the distinguishing and classification of the types and aims of sociological research of urban environment based on the analysis of literature.
\end{abstract}

KEYWORDS: sociological research, sociological research method, urban environment, cityscape, social environment of the city

DOI: http://dx.doi.org/10.15181/tbb.v68i3.857

\section{Ivadas}

Temos aktualumą pagrindžia vis labiau įsigalintis socialinès dimensijos akcentavimas aplinkos formavimo ir pertvarkymo srityje. Sociologinio aspekto reikšmés suvokimas ir integravimas projektuojant bei kuriant aplinką gali būti traktuojamas ir kaip gilias istorines šaknis turintis, ir kaip gana naujas reiškinys. Vienas miesto sociologijos mokslo pradininkų Lietuvoje J. Vanagas (1996) socialinę dimensiją kuriant aplinką sieja su antikos laikų architektūros teorija. Tuo tarpu sociologija yra jaunas mokslas; pats šio mokslo gimimas susijęs su miestų raida - XVIIIXIX a. pramonės revoliucijos sukeltais radikaliais darbo ir gyvenimo pokyčiais 
visuomenėse ir demografine urbanizacija bei jos sukeltais pramoninių valstybių miestų pokyčiais (Giddens, 2005). Sistemingi sociologiniai užstatytos aplinkos tyrimai pradèti vykdyti XX a. pradžioje (Vanagas, 1996). Tik XX a. viduryje prasidẻjo visuomenès ịtraukimo ị miestų planavimą per sociologinius tyrimus procesai. Vienas šios veiklos pradininkų - prancūzų urbanistas P. H. Chombart de Lauwe (Newsome, 2006). Sociologinès užstatytos aplinkos analizès ir miesto sociologijos mokyklų istorinę raidą bei bruožus išsamiai apžvelgė J. Vanagas $(1991,1996)$, A. Giddensas (2005). J. Kamičaitytė-Virbašienè (2003) apžvelgè kraštovaizdžio vizualiosios kokybės tyrimo ir vertinimo taikant sociologinių tyrimų metodus ir i vertinimo procesą integruojant visuomenę tarptautinę patirti bei situaciją Lietuvoje. 2003 m. J. Kamičaitytė-Virbašienė atliko tyrimą ir konstatavo, kad Lietuvoje taikomi kraštovaizdžio tyrimo ir vertinimo metodai tobulintini siekiant integruoti visuomenės vertinimą. Tokią situaciją lėmè istorinès aplinkybės: J. Vanagas (1996) nurodè, kad reguliarūs moksline metodika paremti užstatytos aplinkos sociologiniai tyrimai Lietuvoje pradèti tik septintajame XX a. dešimtmetyje. Tuo tarpu pasaulinėje praktikoje, ypač Vakarų Europoje ir Jungtinèse Amerikos Valstijose, nuo $\mathrm{XX}$ a. pirmosios pusès sociologiniai tyrimai sistemingai taikomi ịvairiems aplinkos aspektams analizuoti. Šiandien įvairūs sociologinių tyrimų metodai vis dažniau taikomi ir Lietuvoje ịvairiems žmogaus pakeisto ir suformuoto kraštovaizdžio tipams tyrinèti: pramoginiams (Kučinskienè, 2012), kelių (Matijošaitienė, 2011), kultūriniams kaimo kraštovaizdžiams ir jų formavimo tradicijų tęstinumo prielaidoms (Misius, 2012).

Šio tyrimo objektas - miestiškasis (antropogeninis, urbanizuotas) kraštovaizdis - žmogaus labai pakeistas, jo veiklos veikiamas, palaikomas ir plètojamas kraštovaizdis (miestai, miesteliai, kompaktiškai užstatytų kaimų ir didelių techninių inžinerinių kompleksų teritorijos) (Lietuvos (...), 2004), jo tyrimo, taikant sociologinius metodus, patirtis ir kryptys.

Darbo tikslas - pateikti sociologinių urbanizuotos aplinkos (miestovaizdžių, miesto medžiaginès ir socialinės aplinkos) tyrimų spektrą, aptarti jų teikiamas galimybes. Siekiant šio tikslo, išskirti sociologinių urbanizuotos aplinkos tyrimų tipai, galimi objektai ir tikslai; jiems iliustruoti pateikti Lietuvoje ir užsienyje atliktų sociologinių urbanizuotos aplinkos tyrimų pavyzdžiai, taip parodant Lietuvos mokslininkų įdirbị šioje srityje tarptautiniame tyrimų kontekste. Siekiant darbo tikslo atlikta sociologijos ir miesto sociologijos sričiu literatūros analizé, išanalizuoti konkretūs sociologinių tyrimų atvejai. 


\section{Sociologinių urbanizuotos aplinkos tyrimų tipai}

Mokslininkų nuomonės dèl subjektyvios dimensijos ir su ja susijusių sociologinių tyrimų reikšmès vertinant ir kuriant aplinką skiriasi. Pavyzdžiui, P. Kavaliauskas (2012) kritikuoja Europos kraštovaizdžio konvenciją. Jo teigimu, iš visų aplinkosauginių koncepcijų ji išsiskiria dominuojančiu populistiniu požiūriu ir net pačioje kraštovaizdžio sampratoje akcentuoja ne objektyvų mokslinį, o subjektyvų vietos gyventojų supratimą ir orientuota ị kokybės tikslo, kaip žmonių siekimų formuluotès, atsižvelgiant i j jų apylinkès kraštovaizdžio ypatumus, supratimą. Tuo tarpu J. Stephenson (2008), G. Swensen ir G. B. Jerpasen (2008) pabrěžia socialinę kraštovaizdžio dimensiją ir vietos bendruomenių, planuotojų bei kitų specialistų apklausų reikšmę tyrinèjant ir vertinant kraštovaizdžius.

Gyvenamosios aplinkos ir kraštovaizdžio bendrai kokybè - vienas svarbiausių darnaus aplinkos vystymosi tikslų. Kraštovaizdžio kokybès tikslas - konkrečiam kraštovaizdžiui kompetentingų valdžios institucijų parengta žmonių siekimų formuluote, atsižvelgiant ị jų apylinkès kraštovaizdžio ypatumus (Kavaliauskas, 2012). Siekiant nustatyti su kraštovaizdžiu ir konkrečiai miestovaizdžiu susijusius žmonių siekius ir prioritetus, gali būti atliekami tiesioginiai ir netiesioginiai sociologiniai tyrimai. Tiesioginiais vadinami tokie tyrimai, kai apie aplinkos kokybę ir jos tikslus tiesiogiai klausiama vietos bendruomenių, atliekamos sociologinès apklausos, rengiamos diskusijos grupėse, viešieji idejjų, koncepcijų svarstymai. Pavyzdžiui, C. Cumberlidge ir L. Musgrave (2007) savo studijoje „Projektavimas ir kraštovaizdžiai žmonėms“ pateikia daug pavyzdžių, kaip visuomenè ir vietos bendruomenès per apklausas ir diskusijas gali būti ịtraukiamos $\mathfrak{i}$ aplinkos kūrimo procesą. Netiesioginiais straipsnyje vadinami tokie tyrimo metodai, kaip stebejjimas ar ekspertinis vertimas, pavyzdžiui, kraštovaizdžio psichologinio-estetinio potencialo ekspertinio vertinimo metodas, miestiečių judrumo, susisiekimo srautų tyrimai. Tokiu atveju galima pasikliauti ekspertų kompetencija ar surinkti empirinius duomenis apie žmonių elgesį, tačiau sudètinga atskleisti elgesio motyvaciją. Urbanizuotos aplinkos sociologinius tyrimus taip pat galima klasifikuoti atsižvelgiant ị tyrèjo ịsitraukimo ị tyrimo procesą (pavyzdžiui, stebejjimas ir pokalbis) ir tyrimo struktūrizacijos (pavyzdžiui, nestruktūrizuotas, laisvas pokalbis ir struktūrizuota apklausa, kai pateikiami klausimai su galimais atsakymo variantais) lygị. Tyrimo metodo struktūrizacijos lygis lemia ir gaunamų duomenų - kokybinių arba kiekybinių - pobūdį. Šiame skyriuje pateikta urbanizuotos aplinkos sociologinių tyrimų klasifikacija pagal metodų tipus ir struktūrizacijos lygị sudaryta remiantis B. Gillhamu (2002), A. Valackiene ir S. Mikène (2008). 


\subsection{Nestruktūrizuotas stebėjimas ir interpretacija}

A. Valackienės ir S. Mikėnès (2008) teigimu, vieni pagrindinių kokybinio tyrimo, skirto suprasti, kaip ir kokiomis aplinkybėmis atsiranda bei veikia šiuolaikinès kultūrinès realijos, metodų yra stebėjimas bei aprašymai. Jų teigimu, šių dienų tyrejjai pripažįsta interpretacinį metodą, kuris pasikliauja tyrèjo nuomone, pojūčiais ir reakcijomis. C. Geertz (2005) taip pat pastebi, kad šiais laikais išryškejjo polinkis socialini gyvenimą interpretuoti kaip tvarkomą simbolių, kurių reikšmę turime įsisąmoninti, kad perprastume tą tvarką ir suformuluotume jos principus. Tokie tyrimų metodai siejami su hermeneutika, kuri jau kuris laikas nustojo būti vien tik tekstų aiškinimo disciplina ir atskleidžia šiuolaikiniuose socialiniuose moksluose vykstantị reiškini, vadinamaji ,žanrų maišymąsi“ (Geertz, 2005; Stanford (...), 2005; Varanauskaitė, 2010). Subjektyvios miesto aplinkos analizès, kuri skirta ne tik aprašyti socialinius faktus, bet ir juos interpretuoti, klasikinis pavyzdys - J. Jacobs (1961) studija „Didžiųjų Amerikos miestų mirtis ir gyvenimas“. Kaip nurodo A. Samalavičius (2010), J. Jacobs pagrindè architektams ir miestų planuotojams visiškai naują miesto analizès metodą: urbanistinès struktūros, miesto erdvių ir komponentų, miesto gyvenimo stebejjimą ir intuicija paremtą asmenišką miesto patyrimą. J. Jacobs (1961) teigimu, miestai yra realios vietos, norėdami suprasti, kaip jie funkcionuoja, naudingos informacijos galime gauti tiesiog stebėdami, kas juose vyksta. Rašydama savo studiją „Didžiųų Amerikos miestų mirtis ir gyvenimas“, ji atliko tuo metu neịprastus „lauko tyrimus“ - keletą metų praleido vaikščiodama po Niujorko gatves su rašikliu ir bloknotu rankoje, stebẻdama ir fiksuodama miesto gyvenimą (Samalavičius, 2010). Iki šiol urbanistų ir architektų vertinamas tokių stebėjimų rezultatas - „,novatoriškas, asmenine patirtimi, plačiu apsiskaitymu ir drąsiomis įžvalgomis pagrịstas požiūris ị miesto planavimą, atsisakymas nagrinèti urbanistinius procesus, remiantis miesto teorijomis, profesionalių planuotojų ir projektuotojų sukurtomis interpretacinèmis schemomis, bet dèmesio sutelkimas $i$ vizualinę ir labai asmenišką patirtį, pasikliovimas individualiu estetiniu jausmu ir miesto socialinès kokybės supratimu, gyva intuicija, nesuvaržyta dogmatiško sekimo jokiais autoritetais“ (Samalavičius, 2010, p. 160). Šiuo metu tokio pobūdžio miesto aplinkos ir kraštovaizdžio tyrimai - subjektyvi miesto aplinkos interpretacija, hermeneutinis socialinės miesto aplinkos aiškinimas, miesto, kaip teksto, analizè - užima reikšmingą vietą greta kitų kokybinių ir kiekybinių miesto aplinkos tyrimų metodų. Neįmanoma tyrinèti socialinio reiškinio be subjektyvaus požiūrio ir interpretacijos, kurie būdingi pačiai žmogaus prigimčiai (Valackienè, Mikẻnė, 2008). Dalis Lietuvos mokslininkų atlieka hermeneutinę miestovaizdžio analizę. Pavyzdžiui, K. Zaleckis (2011) analizuoja miestovaizdị kaip kultūrinị tekstą; 
V. Petrušonis (2005), R. Buivydas (2004), T. Grunskis (2005) - vietos tapatumo klausimus.

\subsection{Struktūruotas stebèjimas}

Taikant struktūruotą sociologinį stebèjimą, būtina iš anksto parengti detalius stebejjimo planus. Toks tyrimas turi būti atliekamas sistemingai, planingai, siekiant numatyto tikslo (Valackienè, Mikènè, 2008, p. 87). Sociologinį stebėjimą tradiciškai galima skirstyti ị stebejjimą dalyvaujant ir stebejjimą nedalyvaujant. Galimi ir skirtingi stebėtojo ịsitraukimo ị tiriamą procesą lygmenys. Klasikinè miesto sociologijos studija, kurioje taikytas stebejjimo dalyvaujant metodas, - tai XX a. paskutiniajame dešimtmetyje M. Duneier atliktas Niujorko „Greenwich Village“ rajono gatvès gyvenimas. Tyrëjas siekè sužinoti, kaip pasikeitė „Greenwich Village“ gatvės gyvenimas nuo J. Jabos studijos laikų. Tyrèjas stebejjo skurstančių juodaodžių vyrų, uždarbiaujančių rajono gatvėse, gyvenimą, pats ịsitraukè į gatvèse vykstančią veiklą pardavinėdamas žurnalus, o tyrimo rezultatus paskelbė studijoje „Šaligatvis“ (Giddens, 2005). Tyrinèjant miesto erdvių funkcionavimą ir jo gerinimo galimybes dažniau pasitelkiami stebejjimo nedalyvaujant arba stebejjimo minimaliai ịsitraukiant ị tiriamą procesą metodai. Tokio tyrimo pavyzdys - G. Stauskio ir E. Eckadt (2011) atliktas viešųjų erdvių Vilniuje ir Veimare tyrimas. Mokslininkai stebejjo žmonių veiklą ir elgesị pasirinktose viešosiose erdvèse abiejuose miestuose ir, remdamiesi stebejimo rezultatais, suformulavo teorines gyvybingų miesto viešujų erdvių projektavimo prielaidas. J. Dixon ir K. Durrheim (2003) atliko neformalios segregacijos tyrimą Pietų Afrikoje, Durbano mieste. Tyrimo tikslas - nustatyti, kaip skirtingų rasių žmonès naudojasi viešosiomis erdvėmis. Struktūruoto stebejjimo metodas taikomas ir žmonių mobilumo tyrimams. Gyventojų mobilumo ir miesto erdvių naudojimo tyrimų yra atlikę Lietuvos mokslininkai P. Juškevičius ir V. Valeika (2007). Miesto erdvių naudojimo ir gyventojų mobilumo tyrimams gali būti pasitelkiamos labai skirtingos priemonès: nuo viešujų erdvių tiesioginio stebejimo su bloknotu rankose ir pokalbių su miestiečiais iki šiuolaikinių kompiuterinių ir palydovinių technologijų. Gerai žinomas mokslo žurnale „Science“ paskelbtas Bostono Šiaurès rytų universiteto Sudètinių tinklų tyrimų centro mokslininko A. L. Barabasi kartu su kolegomis atliktas žmonių judejjimo ir judejimo prognozavimo tyrimas, kuriam duomenis suteikè mobiliojo ryšio bendrové, leidusi fiksuoti šių vartotojų buvimo vietą, remiantis jų telefonų signalų keitimusi su ryšio tinklo bazinėmis stotimis, išsaugant stebimųjų anonimiškumą (Song ir kt., 2010). 


\subsection{Apklausa, interviu ir diskusija}

Apklausa yra populiariausias pirminès sociologinės informacijos rinkimo metodas. Anketinè apklausa - tai susistemintas informacijos iš respondentų rinkimas pateikus anketą. Interviu naudojamas tyrimo informacijai rinkti tiesiogiai ir kryptingai klausėjui bendraujant su respondentu (Gillham, 2002; Valackienè, Mikèné, 2008). Tiek anketinè apklausa, tiek interviu gali būti labai struktūruoti, kai pateikiami galimi atsakymo variantai, ir mažai struktūrizuoti, kai pateikiami atvirieji klausimai ar numatomos tik pagrindinès pokalbio temos (Gillham, 2002). Diskusija, pokalbis grupeje taip pat gali būti traktuojami kaip interviu atmainos. Miesto aplinkos tyrimams naudojami abu informacijos rinkimo būdai. Pavyzdžiui, interviu ,akis ị akị“" ar telefonu ypač tinkamas profesionalų apklausoms. D. Rypkema ir kt. (2011), rengdami apžvalgą ekonominès nekilnojamojo kultūros paveldo įtakos miestams ir regionams įvertinimo tema, 2010-2011 m. atliko interviu su $28 \mathrm{JAV}$ valstybinių institucijų darbuotojais ir paveldosaugos sektoriaus atstovais. Interviu tikslas - patikslinti bendrąsias nuostatas ekonominio paveldo ir paveldosaugos poveikio klausimais. N. Milerius ir kt. (2009) mokomojoje knygoje „Rytu ir Vidurio Europos miestų kaita: architektūriniai, kultūriniai ir socialiniai aspektai“" pateikia Lietuvos architektų, filosofų, menininkų sociologų, urbanistų ir kitų sričių specialistų diskusijas regiono miestams aktualiomis temomis, tokiomis kaip lokalinė architektūra globalizacijos sąlygomis, viešosios erdvès, kolektyvinè atmintis ir kt. Knygoje taip pat pateikiami interviu su žymiais šalies architektais. Šie pirminiai sociologiniai duomenys gali būti sèkmingai naudojami ịvairiuose sociologiniuose tyrimuose. Interviu ir diskusijos grupèse dažnai taikomos vietos bendruomenių nuomonėms ir poreikiams tyrinèti. C. Cumberlidge ir L. Musgrave (2007) pateikia pavyzdžių, kaip diskusijos, bendruomeninė veikla ir net ịvairios užduotys, atliekamos žaidimo forma, padeda išaiškinti ir įvertinti bendruomenių požiūrius bei poreikius. Pavyzdžiui, H. Venhuizen sukūrė žaidimą, pavadinimu „The Making of...", kuris turètų palengvinti diskusijas miesto regeneracijos klausimais tarp vietinès bendruomenès ir komercinių interesų grupių. „The Making of..." remiasi scenarijų kūrimu, kai vietiniai, nacionaliniai ir kiti interesai koordinuojami pasitelkus vaidmenų žaidimą (Cumberlidge, Musgrave, 2007).

Atliekant miesto aplinkos ir jos kūrimo galimybių tyrimus vietoj interviu dažnai atliekamos apklausos raštu, apklausiant profesionalus, vietos bendruomenes ar kitas socialines grupes. Pavyzdžiui, tyrinėdama naujos architektūros kūrimo istorinèje aplinkoje patirti, E. Navickienè (2006) 2002 m. atliko 12 patyrusių architektų, projektuojančių istorinejje Vilniaus, Kauno ir Klaipedos aplinkoje, sociologinę apklausą. Ekspertams pateikta anketa su 15 atvirųų ir iš dalies atvirujų klausimų. 
D. Blair Leach (2011) tyrinejjo vaikų patirtis šiems lankantis istoriniame pastate. Po apsilankymo paveldo objekte vaikų paprašyta aprašyti savo patirtis. Nestruktūruotas vaikų pateiktas ataskaitas mokslininkè tyrinëjo taikydama turinio analizès metodą. Vilniaus senamiesčio atgaivinimo agentūra $2000 \mathrm{~m}$. parenge apklausos anketą Vilniaus senamiesčio gyventojams. Anketoje pateikti 6 atvirieji klausimai, susiję su senamiestyje esančių pastatų tvarkymu ir jo finansavimu. Struktūruota anketinė apklausa, kai ị klausimus raštu atsako respondentai, miesto aplinkos tyrimuose dažniausiai taikoma tais atvejais, kai reikia apklausti didelį skaičių žmonių: šalies, regiono, miesto ar rajono gyventojus, konkrečios paskirties pastatų naudotojus, paveldo objektų lankytojus ir kt. Pavyzdžiui, J. Malcolm-Davies (2004) struktūruotos apklausos metodą taikè istorinių vietovių interpretacijos, pasitelkus istorinius kostiumus, edukacinei reikšmei tyrinèti. Šiame tyrime apklausti atrinktu istorinių vietovių administratoriai ir lankytojai. J. Vanago (1996) teigimu, Lietuvoje dar tarybiniais metais buvo atlikta nemažai sociologinių urbanistinių tyrimų, sukaupta naudingos apklausos anketų sudarymo patirties. Apklausų tikslas - nustatyti miestu gyvenamosios terpès funkcionavimo ypatybes ir tendencijas. J. Vanagas (1996) pateikia anketos, kurią taikant tirtas Kauno Kalniečių gyvenamasis rajonas, pavyzdị. Anketą sudaro 63 klausimai, respondentų teiraujamasi apie esamas gyvenimo sąlygas, planus ir pageidavimus, laisvalaikio leidimo būdus, gyvenamojo rajono infrastruktūrą. Anketine apklausa, kaip ir diskusija, gali tapti bendruomenių integravimo ị aplinkos kūrimo, paveldosaugos procesus priemone. Plètros projekto „Architektūros parkas“, kuriuo siekta nuo Užupio iki Belmonto miško besidriekiančius Vilnios krantus paversti išskirtiniu darnios architektūros kvartalu, iniciatoriai pradiniame jo vystymo etape internetinèje projekto svetainèje atliko Vilniaus gyventojų ir šalies visuomenès apklausą. Respondentams pateikti atvirieji klausimai: teirautasi, kaip jie vertina dabartinę analizuojamų teritorijų situaciją ir kokias jas norètų matyti ateityje (Architektūros parkas, 2008).

\section{Sociologinių urbanizuotos aplinkos tyrimų objektai ir tikslai}

Atlikta sociologinių tyrimų metodų taikymo miesto aplinkos tyrimams apžvalga parodè, kad sociologiniai tyrimai gali būti naudojami įvairiems tikslams, gali būti tiriami labai skirtingi visuomenès segmentai ir surenkami ịvairūs kiekybiniai bei kokybiniai duomenys. Literatūros analizè atskleidè, kad skirtingos miesto sociologijos mokyklos gali taikyti tuos pačius sociologinių tyrimų metodus (Vanagas, 1996; Wood, Landry, 2008). Siekiant pademonstruoti sociologinių tyrimų metodų teikiamas galimybes, tiriant miesto aplinką, šiame skyriuje išskiriamos pagrindinès šių tyrimų tikslų grupės. 


\subsection{Estetikos ir vizualiosios raiškos tyrimai}

Literatūros apžvalga atskleide, kad kraštovaizdžio ir miestovaizdžio estetikos bei vizualiosios raiškos tyrimams pasitelkiamas platus metodų spektras, pradedant stebejjimu ir interpretacija, baigiant sociologinėmis visuomenès apklausomis. Istorinès raidos ir kultūrinio konteksto analize, stebèjimais ir interpretacija grindžiamos urbanizuotos aplinkos estetikos analizès krypčiai galima priskirti jau klasika tapusias ir šiandien iš naujo atrandamas C. Sitte idèjas bei jo $1889 \mathrm{~m}$. publikuotą darbą „Miestų planavimas remiantis meniniais principais“, skirtą estetikos urbanistikoje persvarstymams. A. Samalavičiaus (2011) teigimu, C. Sitte, urbanistikos sampratą grindęs estetikos principais, jau tuo metu įžvelgè moderniojo miesto planavimo idejų nepageidautinas pasekmes ir propagavo tapybišką, psichologiškai jaukią erdvès organizaciją, nepamiršdamas ir praktinių aspektų. C. Sitte koncepciją sudaro istorinių miestų paveldo studijų pagrindu suformuluotos urbanistinio planavimo teorinès prieigos. Praejus daugiau nei šimtmečiui nuo C. Sitte idejjų publikavimo, miestovaizdžio ir kraštovaizdžio estetikos ir vaizdo kokybės problemos ne tik nebuvo išspręstos, bet tapo dar sudètingesnès ir igavo naują mastą. W. Nohl (2001) teigimu, vyraujanti ekonominè ir technologinè modernaus amžiaus orientacija radikaliai pakeitè kultūrinius Europos kraštovaizdžius. Jo teigimu, kraštovaizdžių vaizdinè degradacija kai kur pasiekẻ tokị lygị, kad buvo nebeįmanoma suvokti jų kaip visumos. W. Nohl (2001) teigia, kad ateities kraštovaizdžiai - tai siektini kraštovaizdžio modeliai, kurie turètų būti traktuojami kaip estetikos objektai. Estetinio aplinkos formavimo iššūkiai lemia, kad problemos tyrimams pastaraisiais dešimtmečiais pasitelkiami ne tik dokumentų ir kraštovaizdžio struktūrų analizès metodai ar interpretacijos, bet ir ekspertinio vertinimo bei sociologinių apklausų metodai. XX a. antroji pusė gali būti vadinama sociologijos aukso amžiumi, tad nenuostabu, kad sociologinès apklausos imtos vis dažniau taikyti vertinant estetinị kraštovaizdžio (miestovaizdžio) potencialą (Daniel, 2001). Nepaisant tarybinio laikotarpio suvaržymų ir sociologijos mokslui nepalankaus požiūrio (Vanagas, 1996), tyrimai buvo atliekami ir Lietuvoje: kuriamos tyrimų metodikos, atliekami ekspertiniai vertinimai, visuomenès apklausos. Pavyzdžiui，J. Kamičaitytè-Virbašienė (2003) skiria ekspertinį kraštovaizdžio bendrojo įspūdžio vertinimą, kai subjektyviuoju vertinimu nustatomos tiriamos aplinkos individualios savybès ir vertybès. Ekspertiniam kaimo ir urbanizuoto kraštovaizdžio vertinimui gali būti taikoma dar tarybiniais metais M. Purvino išplètota kraštovaizdžio psichologinio-estetinio potencialo tyrimo metodika, turinti ir struktūrinès bei subjektyvios kraštovaizdžio analizės krypčių bruožų. Šioje 
metodikoje bendras vertinamo kraštovaizdžio psichologinis-estetinis potencialas traktuojamas kaip kraštovaizdžio psichologinių-estetinių išteklių subjektyvusis ir neišmatuojamas kriterijus (Kamičaitytė-Virbašienè, 2003). Kraštovaizdžio ir miestovaizdžio vaizdo kokybės, kaip rekreacinio kraštovaizdžio ištekliaus, tyrimai, paremti visuomenès sociologinėmis apklausomis, Lietuvoje taip pat pradèti dar tarybiniu laikotarpiu. Pavyzdžiui, V. Stauskas, A. Šipaila, G. Daniulaitis, P. Kavaliauskas ir kiti mokslininkai 1962-1986 m. atliko sociologinius tyrimus, kur analizavo poilsio vietos pasirinkimo priežastis. $1986 \mathrm{~m}$. tyrimų duomenimis, kraštovaizdžio struktūros elementų įtaką miesto kraštovaizdžio vaizdingumui respondentai vertino taip: pastatų architektūra $-58 \%$, augalija $-50 \%$, vandens telkiniai - 13\% ir reljefas - $10 \%$ (Kamičaitytè-Virbašienè, 2003). 2003 m. publikuotame kraštovaizdžio vaizdo kokybės reikšmès ir šią kokybę lemiančių veiksnių tyrime J. Kamičaitytė-Virbašienè (2003) gretino sociologinių visuomenės narių ir kraštotvarkos profesionalų apklausų rezultatus. Respondentams vertinti pateikta apklausos anketa ir 10 ịvairaus antropogenizacijos lygio kraštovaizdžio fotografijų. Atliekant ši tyrimą taikytinas semantinio diferencialo metodas.

\subsection{Funkcionavimo, socialinès sudèties ir jų kaitos tyrimai}

Sociologiniai tyrimai - nestruktūruotas ir struktūruotas stebejimas, apklausos, interviu - gali būti naudojami urbanizuotų teritorijų socialinès sudèties ir jos ypatumų, miesto teritorijų funkcionavimo ir naudojimo tyrimams. Šiame kontekste paminèti chrestomatiniai XX a. pradžioje atlikti Čikagos mokyklos tyrimai, paremti stebejimais ir statistinių duomenų analize. R. D. Mc Kenzie, E. W. Burgess, R. E. Parks tyre Čikagos miesto vietinių bendrijų dislokaciją ir jų vidinį funkcionavimą. Mokslininkai nustatè, kad asocialūs reiškiniai po miesto teritoriją buvo pasiskirstę netolygiai: didžiausios jų koncentracijos vietos sutapo su labai prastos kokybės gyvenamaja aplinka; ir atvirkščiai, asocialių reiškinių retėjimas užfiksuotas prestižiniuose aukštos kokybės miesto gyvenamuosiuose rajonuose. Remdamiesi tyrimų rezultatais, Čikagos mokyklos mokslininkai suformulavo idejją, kad žmonių bendruomenèse, panašiai kaip ir natūralioje gamtoje, vyksta kova už būvị, vietą erdveje, miestuose taip pat vyksta tokie biologinei ekologijai būdingi procesai kaip konkurencija, ịsiveržimas ir perėmimas. Remdamiesi šiomis prielaidomis, jie sukūrè tuometinio JAV miesto socialinį-erdvinị modelị (Vanagas, 1996; Giddens, 2005; Wood, Landry, 2008). Dẻl tokio požiūrio Čikagos mokyklos idejos vadinamos ekologine miesto sociologijos kryptimi (Vanagas, 1996; Giddens, 2005). Visai kitaip ị miesto realybę pažvelgė JAV miesto 
sociologas L. Wirth 1938 m. publikuotoje studijoje „Urbanizacija kaip gyvenimo būdas“. Panašiu laikotarpiu kaip ir ekologinè miesto sociologijos kryptis gimusi L. Wirth traktuote, paremta stebejjimu, refleksija ir interpretacija, sutelkta ties tuo, kas yra urbanizacija kaip socialinès egzistencijos forma (Giddens, 2005). L. Wirth išplètota sociopsichologinè miesto sociologijos kryptis daugiausiai dèmesio skyre miestietiškam mentalitetui, ji lemiantiems veiksniams ir jo pasekmėms, žmonių bendravimui ir jo kaitai, visuomeninių grupių susidarymui ir pan. (Vanagas, 1996). A. Giddens (2005) pastebi, kad būtent ekologinè miesto sociologijos kryptis paskatino empirinių miesto aplinkos ir gyvensenos tyrimų plètrą. Empiriniams sociologiniams miesto aplinkos tyrimams priskiriamas ir D. Krupickaitès, H. Standl (2004) atliktas socialinès kaitos tendencijų tyrimas Vilniaus Užupio rajone. Mokslininkai tyrinèjo, ar ir kaip Užupyje reiškiasi gentrifikacija, socialinè kaita, dažniausiai apibūdinama kaip istorinio miesto centro ar kitu istorinių gyvenamujų teritorijų traukos paskatinta socialinè kaita, kai vidurinės ar aukštesnès socialinès klasės gyventojai keičia žemesnès socialinès klasės gyventojus. Šis kompleksinis tyrimas apemė gyventojų apklausą, stebejjimą ir nekilnojamojo turto rinkos duomenų analizę. Kaip siekị suprasti miesto bendruomenių funkcionavimą galima traktuoti ir Ph. Wood, Ch. Landry (2008) parengtą klausimyną diskusijoms su etninių mažumų arba daugiakultūrėmis bendruomenėmis šių bendruomenių ypatumams ir poreikiams suprasti.

\subsection{Potencialo tyrimai ir naujų socialinių koncepcijų kūrimas}

A. Valackienès, S. Mikènès (2008) teigimu, sociologinių tyrimų teikiamos žinios gali būti panaudotos socialinei inžinerijai - kurti naujas visuomenès valdymo, tobulinimo technologijas. Ivairios nuosaikios socialinès inžinerijos formos šiandien sulaukia nemažai miesto sociologų dèmesio. Pavyzdžiui, britų urbanistas Ch. Landry laikosi nuomonès, kad kurti ir valdyti miestus reikia kompleksinès urbanistinès strategijos, paremtos daugelio disciplinų - kultūrinės geografijos, urbanistinès ekonomikos, sociologijos, miestų planavimo, istorijos ir antropologijos, estetikos ir architektūros, ekologijos ir kultūros - studiju įžvalgomis (Samalavičius, 2009). Ch. Landry su kolegomis yra parengęs net keletą tokių miestų valdymo ir raidos koncepcijų, paremtų daugelio sociologinių tyrimų rezultatais, literatūros ir praktinès patirties apžvalga bei pačių autorių įžvalgomis ir interpretacijomis. Viena jų yra „kūrybingo miesto“ koncepcija, paremta darnos ir aplinkos ekologijos, pusiausvyros principais ir ideja, kad kultūrinių funkcijų gausa ir ịvairovė gali užtikrinti pozityvią šiuolaikinių didmiesčių kaitą. 
Koncepcijoje pagrindinis vaidmuo kultūrai ir jos paveldui skiriamas remiantis prielaida, kad šie ištekliai gali susieti istorijas, kolektyvinę atmintị, egzistencijos pojūtị ir suteikti įžvalgų modeliuoti miesto ateitį. Ch. Landry nuomone, šiuolaikiniame mieste kultūra turètų tapti esminiu miesto gyvenimą organizuojančiu principu (Samalavičius, 2009, p. 176). G. Jucevičius (2007), remdamasis literatūros ir pavyzdžių analize, suformulavo ir išplètojo koncepcinę inovatyvaus, arba besimokančio, miesto idèją. Analizuojant urbanizuotos aplinkos potencialą, gali būti atliekami ir nedidelès apimties sociologiniai tyrimai - gyventojų ir ekspertu apklausos, diskusijos ir eksperimentai. Tokio eksperimento pavyzdi pateikia C. Cumberlidge ir L. Musgrave (2007): augančiai naujos statybos gyvenamojo rajono bendruomenei pasiūlyta vaizdžiai išreikšti savo tapatumo su gyvenamaja vieta ir šios vietos potencialo ịvertinimą. Gyventojai galèjo pasirinkti vieną iš skirtingus vertinimus išreiškiančių vẻliavų su užrašais: „aš myliu savo rajoną“, „manau, kad galiausiai viskas bus gerai“, „taip, bet...“, „šiandien čia, rytoj - kitur“ ir „šis rajonas? Ne, ačiū“, vèliavas jie galèjo pakabinti savo butu balkonuose.

\subsection{Kultūrinis ir ekonominis vertinimas}

Sociologinių tyrimų metodai, ypač apklausa, interviu ar diskusija, gali būti taikomi ir netiesioginiams urbanizuotos aplinkos tyrimams. Šioje srityje pažymètini socialinis-ekonominis ir kultūrinis miestovaizdžių bei urbanizuotos aplinkos vertinimai. Pavyzdžiui, D. Rypkema ir kt. (2011) pateikia metodų, kaip ịvertinti socialinį-ekonominị nekilnojamosios kultūros paveldą ir istorinės aplinkos apsaugos projektų potencialą, suvestinę, sudarytą igyvendinant projektą Livable Cities. I suvestinę ịtraukti ir sociologiniai metodai, tokie kaip stebejjimas, interviu, apklausa. Kultūinè vertè - reikšminga, tačiau sunkiai apibrěžiama urbanizuotą aplinką apibūdinanti ir jos formavimą veikianti kategorija. Kaip pastebi E. Avrami ir kt. (2000), J. Stephenson (2007), kultūrinè vertè, tradiciškai laikyta vidine prigimtine objekto savybe, nulemta objektyvių jo savybių, postmodernizmo epochoje imta traktuoti kaip kultūrinio konteksto, vietos ir laiko nulemtas socialinis konstruktas. Ši subjektyvumu ir neapibrěžtumu pasižyminti interpretacija sukèlè vadinamają „vertės krizę“ šiuolaikinejje kultūros teorijoje - kultūrinès vertès samprata išplèsta, tačiau nepasiūlyta tinkama teorija ir metodai, kaip nustatyti šią vertę (Mason, 1999; Throsby, 2002; Holden, 2004). Pastaraisiais dešimtmečiais populiariausias kultūrinès vertės aiškinimo ir nustatymo būdas yra šios vertès skaidymas ị pagrindinius sudedamuosius elementus arba ją lemiančių savybių išskyrimas (Gražulevi- 
čiūtè-Vileniškè, 2009). Mokslininkai pateikia skirtingas kultūrinę vertę lemiančių veiksnių klasifikacijas. Pavyzdžiui, D. Throsby (2002) ir J. Holden (2004) skiria estetinę, dvasinę, visuomeninę, istorinę, simbolinę ir autentiškumo vertes. Estetinei, dvasinei, visuomeninei, simbolinei vertems nustatyti, be kitų metodų, gali būti taikomi sociologinių tyrimų metodai: visuomenès, bendruomenių, ekspertų apklausos, diskusijos grupèse. Sociologiniais tyrimais paremti ekonominio vertinimo metodai urbanizuotai aplinkai ar jos elementams vertinti taikomi tada, kai šie teikia vadinamąsias ne rinkos vertes. Kultūrinių gẻrybių ne rinkos vertėms nustatyti taikomus ekonominio vertinimo metodus daugelis mokslininkų (Throsby, 2002; Mourato, Mazzanti, 2002; Navrud, Ready, 2002) skirsto, atsižvelgdami i individų preferencijų išaiškinimo būdą - preferencijų atskleidimo (angl. revealed preference) ir jų konstatavimo (angl. stated preference). Preferencijų atskleidimo metodai remiasi egzistuojančiais rinkų duomenimis ar faktais apie respondentu elgesį, tuo tarpu preferencijų konstatavimo metodų grupei priskiriami metodai, kuriuos taikant individų sutikimas mokèti nustatomas, remiantis jų teiginiais apie numatomą jų elgesį ateityje hipotetinėmis aplinkybėmis. Vienas populiariausių antrajai grupei priskiriamų sociologiniais tyrimais paremtų metodų - numatomojo vertinimo (angl. contingent valuation method). Taikant ši metodą, respondentams pildant anketą ar duodant interviu prašoma ịvardyti maksimalią pinigų sumą, kurią jie sutiktų mokèti už vertinamą kultūrinę gèrybę ar su ja susijusius privalumus esant tam tikroms hipotetinėms aplinkybėms. Literatūros analizè atskleidè, kad šis metodas taikytas istoriniams statiniams ir pastatams, istoriniams pastatų kompleksams bei istorinėms vietovėms vertinti (Gražulevičiūtė-Vileniškè, 2009). Metodo taikymo istoriniams statinių ir pastatų kompleksams patirtis apima sakralinių ansamblių (Mourato ir kt., 2002), miestų aikščių (Alberini ir kt., 2003) ir rezidencijų ansamblių (pvz., Kim ir kt., 2007) vertinimo atvejus. Nors metodo praktinis taikymas kelia su rezultatų patikimumu ir tikslumu susijusių iššūkių (GražulevičiūtèVileniškè, 2009), vertinimo rezultatai naudingi atskleidžiant urbanizuotos aplinkos socialinį-ekonominị potencialą, kuris liktų nepastebètas, taikant ịprastinius kultūrinio ir ekonominio vertinimo metodus. 


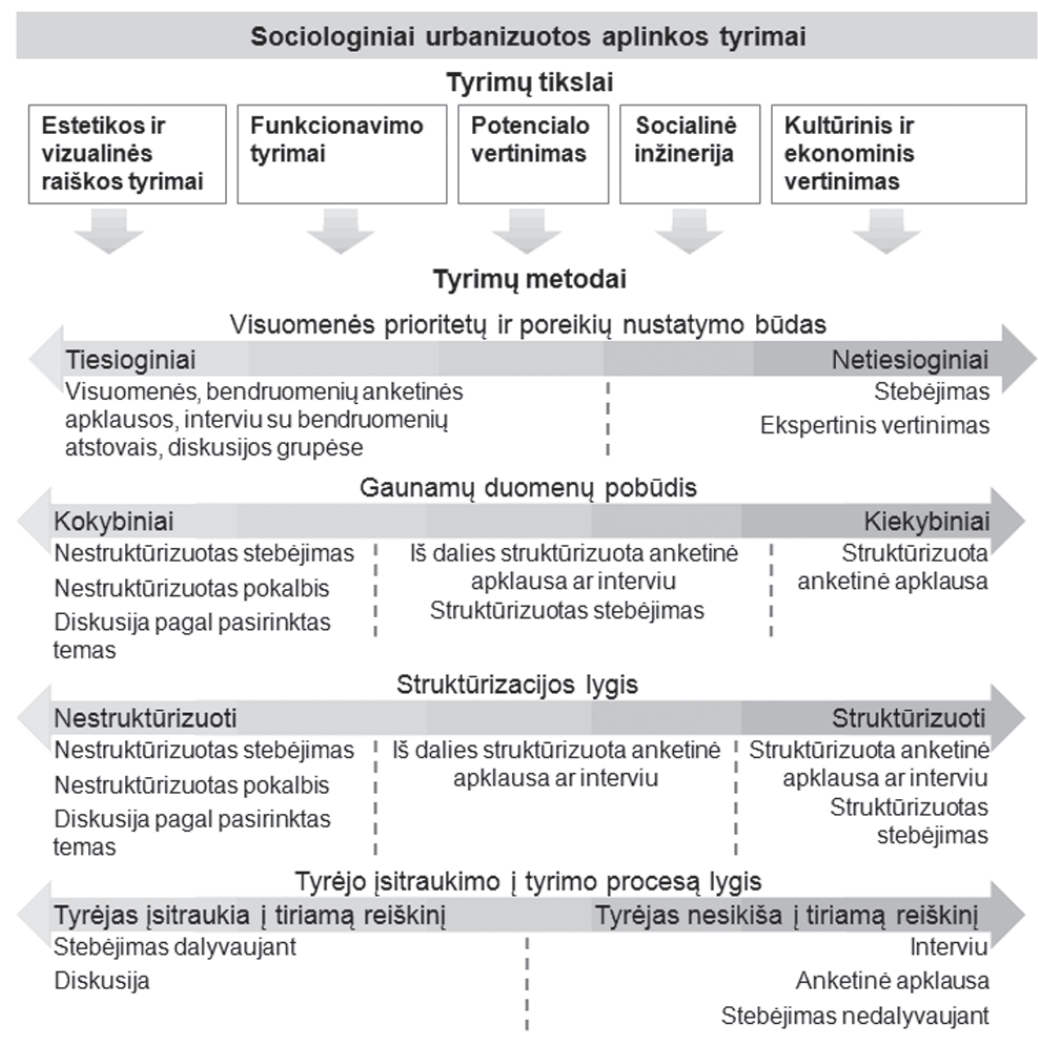

1 pav. Kai kurios sociologinių urbanizuotos aplinkos tyrimų klasifikacijos Fig. 1. Some classifications of sociological research of urban environment

\section{Išvados}

1. Atliktas tyrimas atskleidè sociologinių tyrimų reikšmę urbanizuotos aplinkos tyrimams ir jos formavimui. Sociologijos mokslas gimè kartu su miestų plètra XVIII-XIX a., o sistemingi miesto sociologijos tyrimai pramoniniuose miestuose pradèti vykdyti XX a. pirmojoje pusejje. Lietuvoje miesto sociologijos mokslo pradininkas J. Vanagas empirinius šios srities tyrimus pradejjo vykdyti septintajame XX a. dešimtmetyje. Šiuo metu Lietuvoje, be hermeneutinių, menotyrinių miestovaizdžio tyrimų, atliekami tyrimai, paremti empirinemis-sociologinėmis apklausomis, interviu, stebejjimo metodais. Straipsnyje išskirtiems tarptautinès reikšmès miesto sociologijos tyrimų atvejams pavyko aptikti bent jau iš dalies analogiškų tyrimų, atliktų Lietuvoje, atvejų. 
2. Sociologinių urbanizuotos aplinkos tyrimų metodų apžvalga atskleidè, kad egzistuoja platus spektras metodų, - nuo nestruktūruoto stebejjimo ir interpretacijos iki struktūruotos anketinès apklausos - leidžiančiu suprasti socialinę miesto aplinkos dimensiją. Šie metodai gali būti skirstomi ị tiesioginius ir netiesioginius pagal visuomenès prioritetu ir poreikių nustatymo būdą, ị kiekybinius ir kokybinius - pagal surinktų duomenų pobūdį, ị mažai struktūruotus ir labai struktūruotos - pagal struktūravimo ir tyrèjo ịsitraukimo į tyrimų procesą lygị: tyrejjas įsitraukia į tiriamą reiškinị ir tyrimus arba išlieka nešališkas ir nesikiša ị tiriamą reiškinị.

3. Tyrimas atskleidè sociologinių urbanizuotos aplinkos tyrimų objektų ịvairovę: tyrimų objektais gali būti vizualioji miesto aplinkos raiška, urbanizuotos teritorijos funkcionavimas, socialinè sudètis ir jos kaita, kultūrinis, socialinis, ekonominis urbanizuotos aplinkos potencialas. Remiantis sociologinių tyrimų duomenimis, gali būti kuriamos naujos miestų raidos koncepcijos, pvz., „kūrybingas miestas“, „,besimokantis miestas“. Šių tyrimų objektų grupių tikslų galima siekti taikant įvairius metodus: kraštovaizdžiu ir miestovaizdžių estetikos ir vizualiosios raiškos tyrimams taikomas stebėjimas, ekspertinis vertinimas ir visuomenès apklausos; funkcionavimo, socialinès sudèties ir jos kaitos tyrimams gali būti taikomas stebèjimo metodas ir apklausos; urbanizuotos aplinkos potencialo tyrimams galima taikyti įvairius metodus - nuo interpretacijos iki struktūruoto stebejjimo ir anketinių apklausų.

Gauta 20140707

Pasirašyta spaudai 20140929

\section{Literatūra}

Alberini, A., Longo, A. (2006). Combining the travel cost and contingent behaviour methods to value cultural heritage sites: evidence from Armenia. Journal of Cultural Economics 30 (4): 287-304.

Alberini, A., Riganti, P., Longo, A. (2003). Can people value the aesthetic and use services of urban sites? Evidence from a survey of Belfast residents. Journal of Cultural Economics 27 (3/4): 193-213.

Avrami, E., Mason, R., De la Torre, M. (2000). Values and Heritage Conservation. Research Report. Los Angeles: Getty Conservation Institute.

Architektūros parkas. (2008). [Interaktyvus]. Prieiga internete: http://www.archparkas.vilnius.lt/main.php [žiūrèta 20130120$]$.

Blair Leach, D. (2011). Children's recollections of a historic house visit: recall of experiences and use of cognitive tools. Visitor Studies 14 (1): 34-47.

Buivydas, R. (2004). Vilniaus senamiestis: semantinis gamtos elementų vaidmuo. Urbanistika ir architektūra 28 (1): 3-8.

Boxall, P., Englin, J., Adamowicz, W. (2003). Valuing aboriginal artifacts: a combined revealed-stated preference approach. Journal of Environmental Economics and Management 45 (2): 213-230.

Cumberlidge, C., Musgrave, L. (2007). Design and Landscape for People. Thames and Hudson. 


\section{SOCIOLOGINIAI URBANIZUOTOS APLINKOS TYRIMAI: PATIRTIS IR KRYPTYS}

Daniel, T. C. (2001). Wither scenic beauty? Visual landscape quality assessment in the $21^{\text {st }}$ century. Landscape and Urban planning 54: 267-281.

Dixon, J., Durrheim, K. (2003). Contact and the ecology of racial division: some varieties of informal segregation. British Journal of Social Psychology 42 (1): 1-23.

Geertz, C. (2005). Kultūru interpretavimas. Vilnius: Baltos lankos.

Giddens, A. (2005). Sociologija. Kaunas: Poligrafija ir informatika.

Gillham, B. (2002). Developing a Questionnaire. London: Continuum.

Gražulevičiūtè-Vileniškè, I. (2009). Nekilnojamojo kultūros paveldo ne rinkos vertinimas: teorinis kontekstas ir galimybès. Daktaro disertacija. Kaunas: Kauno technologijos universitetas.

Grunskis, T. (2005). Vietos tapatumo krizė Vilniaus centro raidoje (erdvès morfologijos diskurse). Urbanistika ir architektūra 29 (1): 13-18.

Holden, J. (2004). Capturing Cultural Value. How Culture Has Become a Tool of Government Policy. London.

Jacobs, J. (1961). The Death and Life of Great American Cities. New York: Random House.

Juškevičius, P., Valeika, V. (2007). Lietuvos miestų sistemu raida. Vilnius: Technika.

Jucevičius, G. (2007). Inovatyvūs miestai ir regionai. Kaunas: Technologija.

Kamičaitytė-Virbašienė, J. (2003). Kraštovaizdžio vizualinès kokybès reguliavimas kraštotvarkoje. Daktaro disertacija. Kaunas: Kauno technologijos universitetas.

Kavaliauskas, P. (2012). Kraštovaizdžio formavimo (siektinu kraštovaizdžio etalonu) metodika. Siektinos kraštovaizdžio kokybès tikslo koncepcija. Tarpinè ataskaita. Vilnius: Vilniaus universitetas.

Kim, S. S., Wong, K. K. F., Cho, M. (2007). Assessing the economic value of a World Heritage Site and willingness-to-pay determinants: a case of Changdeok Palace. Tourism Management 27 (1): 317-322.

Krupickaitė, D., Standl, H. (2004). Socialinė kaita (gentrification) Vilniaus Užupyje. Urbanistika ir architektūra 28 (4): 165-174.

Kučinskienè, J. (2012). The Socio-Ecological Paradigm of the Landscape Resources Re-use. Summary of doctoral Dissertation. Kaunas: Kaunas University of Technology.

Lietuvos kraštovaizdžio politikos krypčių aprašas. (2004). Patvirtinta Lietuvos Respublikos Vyriausybės $2004 \mathrm{~m}$. gruodžio 1 d. nutarimu Nr. 1526.

Matijošaitienè, I. (2011). The Principles of Formation of Hedonomic Road Landscape. Summary of doctoral dissertation. Kaunas: Kaunas University of Technology.

Mason, R. (1999). Economics and Heritage Conservation: Concepts, Values and Agendas for Research. Economics and heritage conservation. Los Angeles: The Getty Conservation Institute, p. 2-18.

Malcolm-Davies, J. (2004). Borrowed robes: the educational value of costumed interpretation at historic sites. International Journal of Heritage Studies 10 (3): 277-293.

Milerius, N., Tornau, U., Dranseika, V. (2009). Rytu ir Vidurio Europos miestų kaita: architektūriniai, kultūriniai ir socialiniai aspektai. Vilnius: Vilniaus universiteto leidykla.

Misius, R. (2012). Artificial Planting Traditions in Individual Homesetads of Lithuanian Farmers: Activity Heritage from the History and Theory of Arts Point of View. Summary of doctoral dissertation. Kaunas: Kaunas University of Technology.

Mourato, S., Mazzanti, M. (2002). Economic Valuation of Cultural Heritage: Evidence and Prospects. Los Angeles: Getty Conservation Institute.

Mourato, S., Kontoleon, A., Danchev, A. (2002). Preserving cultural heritage in transition economies: a contingent valuation study of Bulgarian monasteries. In: S. Navrud, R. C. Ready. Valuing cultural heritage. Applying environmental valuation techniques to historic buildings, monuments and artefacts. Cheltenham: Edward Elgar, p. 68-85.

Navrud, S., Ready, R. C. (2002). Methods for valuing cultural heritage. In: S. Navrud, R. C. Ready. Valuing cultural heritage. Applying environmental valuation techniques to historic buildings, monuments and artefacts. Cheltenham: Edward Elgar, p. 10-28.

Navickienè, E. (2006). Nauja architektūra istorineje aplinkoje: kūrimo patirtis. Vilnius: Technika.

Newsome, B. W. (2006). Chombart de Lauwe, Paul-Henry (1913-1998). In: R. P. Domenico, M. Y. Hanley. Encyclopedia of Modern Christian Politics. London: Greenwood Press, p. 116-117.

Nohl, W. (2001). Sustainable landscape use and aesthetic perception - preliminary reflections on the future of landscape aesthetics. Landscape and Urban planning 54 (1): 223-237.

Petrušonis, V. (2005). Vietovès kultūrinio tapatumo ontologija. Urbanistika ir architektūra 29 (2): 55-62. 
Rypkema, D., Cheong, C., Mason, R. (2011). Measuring Economic Impacts of Historic Preservation [interaktyvus]. A report to the Advisory Council on Historic Preservation. Prieiga internete: http://www.placeeconomics.com/wpcontent/uploads/2012/02/economic-impacts-of-hp.pdf [žiūrèta 201301 20].

Samalavičius, A. (2009). Vartojantis ar kūrybingas miestas? Logos 61: 170-178.

Samalavičius, A. (2010). Miesto kultūros žymėjimas ir Jane Jacobs. Logos 63: 157-164.

Samalavičius, A. (2011). Estetika urbanistikoje: Camillo Sitte įžvalgos. Logos 69: 141-149.

Song, C., Qu, Z., Blumm, N., Barabási, A. L. (2010). Limits of predictability in human mobility. Science 327 (5968): 1018-1021.

Stauskis, G., Eckadt, E. (2011). Empowering public spaces as catalysers of social interactions in urban communities. Urbanistika ir architektūra 35 (2): 117-128.

Stephenson, J. (2008). The Cultural Values Model: an integrated approach to values in landscapes. Landscape and Urban Planning 84 (2): 127-139.

Swensen, G., Jerpasen, G. B. (2008). Cultural heritage in suburban landscape planning. A case study in Southern Norway. Landscape and Urban Planning 87 (4): 289-300.

Throsby, D. (2002). Economics and Culture. Cambridge: Cambridge University Press.

Wood, Ph., Landry, Ch. (2008). The Intercultural City. Planning for Diversity Advantage. London: Earthscan.

Valackienè, A., Mikènè, S. (2008). Sociologinis tyrimas. Metodologija ir atlikimo metodika. Kaunas: Technologija.

Vanagas, J. (1991). Sociologinės minties urbanistikoje ištakos. Urbanistika ir rajoninis planavimas 17.

Vanagas, J. (1996). Miesto sociologijos pagrindai. Vilnius: Aldorija.

Varanauskaitè, L. (2010). Vytauto Kavolio kūrybos lauko žemèlapis: teoriniu ir metodologiniu prielaidu analizè. Magistro darbas. Vilnius: Vilniaus universitetas.

Zaleckis, K. (2011). Globalizacijos atspindžiai miesto kūne: keletas įžvalgų. Logos 66: 142-152.

\section{SOCIOLOGICAL RESEARCH OF URBAN ENVIRONMENT: EXPERIENCE AND TRENDS}

\section{Indrè Gražulevičiūtè-Vileniškè}

\section{Summary}

The social dimension is gaining an increasing importance in the fields of shaping our environment, such as territorial planning and architectural design. The perception of the importance of sociological research and its integration into the fields of architectural design and environmental management can be seen both as having deep historical roots and as quite recent phenomenon. One of the pioneers of urban sociology in Lithuania J. Vanagas links the social dimension in the shaping of our living environment with the architectural theory of the classical antiquity. Meanwhile, the sociology itself is a young discipline; the birth of it is closely linked with urban development - with radical changes of life and work and demographic urbanization brought by the industrial revolution of the $18^{\text {th }}$ and $19^{\text {th }}$ centuries and the consequent changes of cities in the industrialized countries. Systematic sociological analysis of the built environment was initiated only in the beginning of the $20^{\text {th }}$ century. In the middle of the $20^{\text {th }}$ century the processes of 
inclusion of the society into urban planning through sociological research were started. One of the initiators of these activities was French urbanist P. H. Chombart de Lauwe. J. Vanagas and A. Giddens had systematically reviewed the historical development of sociological analysis of the built environment and the schools of urban sociology. J. Kamičaitytė-Virbašienè had reviewed the methods of landscape visual quality analysis and assessment using sociological analysis and the foreign and Lithuanian experience of the inclusion of the society into valuation process through sociological research. In her research carried out in 2003 she concludes that the landscape assessment methods applied in Lithuania should be improved from the point of view of integration of the society. Such situation was conditioned by the historical circumstances - according to J. Vanagas, the systematic urban sociology research based on scientific methodology were initiated only in the 60' of the $20^{\text {th }}$ century in Lithuania. Meanwhile in Western Europe and the United States sociological research was applied for analysis of different aspects of the built environment starting with the beginning of the $20^{\text {th }}$ century.

The object of this research is urban (anthropogenic, urbanized) landscape landscape strongly transformed, influenced, maintained, and developed by human activities (cities, towns, densely built villages, large technical engineering complexes) - and the experience and trends of its analysis applying sociological research.

In order to create the living environment, which would be not only comfortable, but also aesthetic and psychologically acceptable, the aim of the research - to analyze the experience and possibilities of application of sociological research methods to physical and social environment of urbanized areas - becomes increasingly relevant. In order to reach this aim, the article presents the review of experience of application of sociological research methods to urban environment distinguishing the characteristic cases in this field and their analogies in Lithuanian practice and the distinguishing and classification of the types and aims of sociological research of urban environment based on the analysis of literature.

Today in Lithuania various sociological research methods are being increasingly applied for the analysis of different landscape types transformed or shaped by human influence from traditional cultural landscapes to entertainment and road landscapes. Currently the research of urban environment in Lithuania encompasses both the hermeneutic analysis and interpretation and the empirical research including surveys, interviews, and observations. The distinguished cases of sociological research of urban environment of international significance have at least similar analogies in Lithuanian practice as well.

The review of the methods of sociological research of urban environment has demonstrated that the wide spectrum of methods, ranging from interpretations to 
surveys using structured questionnaires, allows the better understanding of the social dimension of urban environment. The methods can be classified into direct and indirect according to the way how the needs and priorities of the society are determined, into quantitative and qualitative according to the type of obtained data, into non-structured and structured according the level of structuring of the research process and instruments, and, according the level of the involvement of the researcher into the phenomenon under analysis, into the research, where the researcher participates in the phenomenon under analysis and the research, where the researcher observes the phenomenon impartially.

The research has revealed the wide spectrum of the objects of the sociological research of the urban environment; the objects of research include the visual expression of the urban environment, the functioning, social composition of the urban environment and their changes, the cultural, social, and economic potential of the urban environment; the new concepts of urban development, such as "creative city", "learning city" can be developed based on the data provided by the sociological research. To reach the objectives of each of these groups of aims of sociological research various methods can be used: observations, expert surveys and surveys of public preferences can be used in the research of aesthetics and visual features of urban environment, observations and surveys can be applied the research of functioning and social composition of the urban environment, the wide spectrum of methods ranging from interpretation to structured observations and surveys using structured questionnaires can be applied in the analysis of different aspects of potential of urban environment.

The research had demonstrated that sociological research provides the wide possibilities for understanding and forming urban environment. The urbanists and sociologists reveal numerous new aspects and challenges concerning the integration of social dimension into the processes of formation of the built environment. 